\title{
SECULARISMO NO DIREITO - INFLUÊNCIA RELIGIOSA NAS SENTENÇAS: UMA PERSPECTIVA SOBRE O RESPEITO AOS DIREITOS INDIVIDUAIS
}

\section{Cristiane Catarina Fagundes de Oliveira* Romulo André Alegretti de Oliveira** João Roberto Assunção Soares****}

\section{INTRODUÇÃO}

A imparcialidade deve ser uma obsessão da atividade jurisdicional, que é uma função estatal fundamental no Estado Democrático de Direito. É necessário que a Justiça trate todos de forma igual, um pressuposto básico do liberalismo, tese dominante nas democracias ocidentais. Dentro de tal ótica de um Estado isento, desenvolveram-se, principalmente a partir do século XV, a secularidade e a laicidade, que significam o afastamento do Clero dos assuntos do Estado.

Como pode ser observado no desenvolvimento deste ensaio, a separação entre Igreja e Estado foi fundamental para o surgimento e o estabelecimento do Estado Moderno no Ocidente. Isso porque a organização liberal ideal prevê um ente estatal totalmente impessoal para quem todos cedam um pouco de sua

\footnotetext{
* Doutora em Direito/USP. Professora do Curso de Direito do IPA. Procuradora Municipal de Porto Alegre

** Mestre em Direito. Professor Universitário. Analista do Ministério Público da União

*** Bacharel em Direito pela Faculdade CNEC Gravataí. Bacharel em Comunicação Social - Jornalismo pela PUCRS.
} 
liberdade em troca de segurança e garantias para o desenvolvimento de suas atividades.

Antes do período de ampliação das liberdades individuais consolidadas, principalmente a partir do século XVIII, com o advento das revoluções burguesas, os Estados ocidentais viviam uma grande influência da Igreja católica. Era ela quem ditava as normas do saber jurídico, do conhecimento científico, bem como do comportamento em geral.

Nessa senda, havia uma limitação à liberdade de pensamento e de criação, uma vez que tudo tinha de ser chancelado pela Igreja. Ao mesmo tempo, a civilização Ocidental viveu um período em que o Estado era personificado na figura do rei. Muito diferente da impessoalidade que se vive hoje.

Com o avanço do pensamento científico, intelectual e literário fora dos ditames do cristianismo, notadamente a partir do século XV, quando Nicolau Copérnico divulgou sua teoria Heliocêntrica, a qual defendia que a Terra girava em torno do Sol e não o contrário, como atestava a Igreja, houve avanço em várias áreas. Ganha força no meio intelectual a defesa das liberdades individuais, com destaque para pensadores como John Locke, Thomas Hobbes e Jean-Jaques Rousseau.

Em contraponto ao avanço das ideias contrárias à Igreja, o Clero, instalado no poder estatal, passou a perseguir e punir severamente seus opositores na chamada inquisição. Neste período, pessoas eram presas e condenadas, sem direito ao contraditório, pelo simples fato de discordarem da Igreja. 0 modelo inquisitivo perdurou por muito tempo, inclusive no início do Estado moderno. É possível percebê-lo ainda hoje em ditaduras governamentais.

Em oposição ao modelo inquisitivo de justiça e desenvolvendo-se paralelamente à secularidade e à laicidade, há o modelo garantista, o qual tem como objeto a busca da imparcialidade e da ampla defesa, partindo-se do pressuposto que o sujeito deve ser julgado pelo que fez e não pelo que é, como ocorria na inquisição. 
Esta é a lógica jurídica do liberalismo. Desta forma, o julgamento nos Estados ocidentais modernos, liberais - ou quase -, em sua maioria, é baseado na lei e não no "sentimento" do julgador. Ou seja, o Estado ao dizer o direito deve ser objetivo. De modo que, ao menos em tese, o que vale para um vale para todos.

Nesse sentido, é necessário que o Estado, detentor do monopólio da punição (violência) tenha equilíbrio na aplicação das sanções. A lei é um limitador do poder estatal, pois de forma pública é feita pelo povo, por meio de seus representantes, ela deve refletir a ideia média da população em relação às questões que regula, inclusive no âmbito penal. Essa é a regra no Estado liberal.

Este ensaio objetiva perquirir por meio de um apanhado histórico e através da análise de sentenças exemplificativas utilizadas como parâmetros, a laicidade do Estado e a busca da atividade estatal equilibrada.

\section{ALGUMAS DEFINIÇÕES SOBRE ESTADO LAICO E SECULARIZAÇÃO}

\subsection{CONCEITO DE ESTADO LAICO}

Laico, de acordo com a definição do Dicionário Eletrônico Aurélio $^{1}$, é o Estado que não tem orientação religiosa, ou seja, diante das diversas religiões, seitas ou qualquer tipo de entidade de orientação espiritual seguida pela população, adota-se uma posição de neutralidade. Significa que não se coíbe ou embaraça o exercício da espiritualidade, tampouco se patrocina algum pensamento religioso.

O Brasil é um exemplo de país laico. A base legal está na Constituição Federal que prevê a laicidade, entre outros, em seu artigo 5ํㅜ, incisos VI, VII e VIII e também no artigo $19^{2}$, inciso I, conforme descrito a seguir:

Dicionário Eletrônico Aurélio. 4 ${ }^{\mathrm{a}}$ Ed. Positivo Informática Ltda. 2009.

2 http://www.planalto.gov.br/ccivil_03/Constituicao/Constituicao24.htm. Acesso em $02 / 04 / 2017$ 
Art. 19. É vedado à União, aos Estados, ao Distrito Federal e aos Municípios:

I - Estabelecer cultos religiosos ou igrejas, subvencioná-los, embaraçar-lhes o funcionamento ou manter com eles, ou seus representantes, relações de dependência ou aliança, ressalvada, na forma da lei, a colaboração de interesse público.

Há de se deixar claro, por conta disso, que não se pode confundir o Estado laico com o Estado ateu. Neste, haveria uma posição de contrariedade à religião. Conforme demonstra o texto constitucional acima exposto, o Brasil, bem como, qualquer Estado Laico não se envolve - ou ao menos não deveria se envolver - com as manifestações religiosas. Há uma posição de neutralidade. As orientações espirituais ficariam dentro da seara das liberdades individuais, um valor bastante caro ao pensamento liberal (FERRAJOLI, 2002, p. 31), que é muito influente na política e na cultura ocidental.

Nessa conformidade, não se pode deixar de considerar que as religiões, ao longo da história, influenciaram Estados e governos e vice-versa. Um dos exemplos mais contundentes na história foi o do Império Romano que, ao adotar o cristianismo nos séculos IV e V d.C. como religião oficial, contribuiu para a divulgação, bem como a consolidação da igreja cristã no ocidente. Ao mesmo tempo, o cristianismo foi se inserindo na estrutura do império muito além das questões espirituais. Pirateli e Pereira $\mathrm{Melo}^{3}$ ilustram o acima exposto:

Com a dissolução do mundo antigo e a ascensão da Igreja, esta não limitou seu papel ao campo espiritual, mas, como nova condutora do orbis - pelo

3 PIRATELI, Marcos Roberto; PEREIRA MELO, José Joaquim. Agostinho e a Igreja Como Espaço de Formação no Fim da Antiguidade. Revista Jornada de Estudos Antigos e Medievais. p. 6. Disponível em http://www.ppe.uem.br/ jeam/anais/2013/pdf/42.pdf. Acesso em 10/10/2016. 
menos na parte ocidental - não pode se ausentar das questões civis, de tal modo que sua política de moralização da vida pública contribuiu para a consolidação da vida servil.

A relação entre religião e Estado é uma constante na história, bem como, a produção de conhecimento vinculada ou não a dogmas espirituais. Na Idade Moderna, a Europa ocidental passa a viver uma onda de separação entre Estado e Igreja. Este fenômeno tem sua ampliação com o surgimento do Estado Moderno advinda dos ideais das revoluções burguesas do século XVIII cuja liberdade era um fator preponderante.

Seguindo a análise sobre o surgimento da norma tal como conhecida nos tempos atuais, Gauer (GAUER, 2009, p. 140) avalia que a estrutura jurídica como se conhece hoje, tem início a partir da tomada do saber jurídico pelos cientistas em detrimento da Igreja alcançado a partir da modernidade, de 1492 a 1789.

A estrutura jurídica se fez a partir da secularização, como tentativa de eliminar a sacralidade, o princípio secularizador; constitui-se, portanto, como elemento estruturador das sociedades ocidentais modernas, que reivindicaram para si a verdade como substância afirmada em si e negada no outro (a seu tempo excluído como alguém infiel), mas que assumiram uma verdade, índice de si mesma. Esta verdade é excessiva por natureza.

A sociedade europeia da Idade moderna passa por uma série de mudanças que favorecem a cisão entre Estado e Igreja. A busca por mais liberdade em detrimento da servidão, a descoberta de um novo mundo, neste caso, a América, e as descobertas científicas tornaram as possibilidades do homem maiores. Neste contexto, Carvalho considera que a laicização se torna um processo inevitável (Carvalho, 2008, p. 23): 
$\mathrm{Na}$ redescoberta do homem como medida de todas as coisas, com o ingresso do 'Novo Mundo' no cenário histórico, e com a visualização de um novo estado de coisas no qual liberdade e igualdade se opõem à servidão, o impulso da laicização das ciências torna o processo secularizador inevitável. Da exclusão do diverso nasce a ideia de tolerância, da barbárie inquisitiva afloram teorias civilizatórias. Surge o racionalismo, e a capacidade crítica do homem é revelada.

Note-se na manifestação acima descrita que o processo em busca das liberdades individuais que vivia a Europa ocidental, encaminhava aquela sociedade inevitavelmente para o processo de secularização. Ou seja, a "ampliação do mundo" por meio do pensamento caminhava na direção da diminuição da influência da Igreja.

\subsection{CONCEITO DE SECULARIZAÇÃO}

Secularização é o termo utilizado para denominar a ruptura da cultura eclesiástica com as doutrinas filosóficas e instituições jurídico-políticas, conforme ensinamento de Carvalho ${ }^{4}$. 0 sociólogo Max Weber foi quem conceituou referido fenômeno social. No entanto, de acordo com Antônio Flávio Pierucci ${ }^{5}$, o pensador alemão utilizou pouco o termo, que viria a se popularizar futuramente, mas lidou com o conceito conhecido hoje como processo de secularização.

4 CARVAlHO, Salo de. Revisita à Desconstrução do Modelo Jurídico Inquisitorial. Revista da Faculdade de Direito UFPR. p. 42. Disponível em http:// revistas.ufpr.br/direito/article/viewFile/5183/3898. Acesso em 10/10/2016.

5 PIERUCCI, Antônio Flávio.A Secularização em Max Weber - Da contemporânea serventia de voltarmos a acessar* aquele velho sentido**. Revista Brasileira de Ciências Sociais. Volume 13. No 37 Disponível em http://www. scielo.br/scielo.php?script=sci_arttext\&pid=S0102-69091998000200003. Acesso em 05/02/2017. 
Na interpretação de Pierucci, Weber considerava o que chamamos de secularização "como a luta da modernidade cultural contra a religião, tendo como manifestação empírica no mundo moderno o declínio da religião como potência in temporalibus, seu disestablishment". Como pode ser observado na passagem a seguir (WEBER, 1981, p. 27):

(...) grandes financistas que promoveram essa mudança, aparentemente imperceptível, mas na verdade tão decisiva para a penetração do novo espírito na vida econômica (...). Somos tentados a pensar que tais qualidades éticas pessoais não tenham a mais leve relação com máximas éticas, para não dizer ideias religiosas, mas sim que a relação entre elas seja negativa. A capacidade de se livrar da tradição comum, um tipo de Iluminismo liberal, parece ser a base mais adequada para o sucesso de tal homem de negócios. E nos dias atuais, costuma ser exatamente esse o caso. Qualquer relação entre crenças religiosas e a conduta é em geral ausente e, quando existe pelo menos na Alemanha, ela tende a ser negativa. As pessoas imbuídas do espírito do capitalismo tendem, hoje, a ser indiferentes, se não hostis, à Igreja. A ideia de beata monotonia do paraíso exerce pouca atração sobre sua natureza ativa; a religião se lhes apresenta como um meio para afastar as pessoas do trabalho neste mundo (...).

Tal ruptura se deu porque o conhecimento científico alcançado no século 15 se tornou incompatível com certas lições/ dogmas da Igreja, conforme já mencionado anteriormente. Carvalho $^{6}$ aponta que o pensamento de Nicolau Copérnico (1473 a 1543) foi fundamental, de modo que este desenvolveu a teoria

6 CARVAlHO, Salo de. Revisita à Desconstrução do Modelo Jurídico Inquisitorial. Revista da Faculdade de Direito UFPR. p. 42. Disponível em http:// revistas.ufpr.br/direito/article/viewFile/5183/3898. Acesso em 10/10/2016. 
heliocêntrica, na qual defendia que a Terra, e outros planetas, girariam em torno do sol. Foi uma séria contraposição a uma das principais teorias científicas da Igreja, o Geocentrismo, que defendia a Terra como sendo o centro do universo.

A Igreja, detentora do saber científico ocidental, até então, passa a ter suas teses severamente questionadas. No campo político-jurídico isto não é diferente, o questionamento dos dogmas cristãos dá espaço para pensadores como Thomas Hobbes, John Locke e Jean-Jaques Rousseau, entre outros, a vislumbrarem (e defenderem) um mundo sob a plenitude da igualdade e da liberdade de consciência.

Ao mesmo tempo, o próprio pensamento religioso também passava por severas discussões acerca da existência de Deus ou mesmo quanto à veracidade da fé. Desde a reforma protestante ${ }^{7}$ a igreja cristã já vinha sofrendo abalo em seu seio. Conforme aponta Baumer (BAUMER, 1977, pp. 87-95), em que pese reformadores como Lutero e Calvino não questionassem a existência de Deus, suas ideias de reforma na estrutura da Igreja, somada ao embate de pensamento entre fideístas e céticos, ajudaram a abalar o catolicismo e seu poder no século XVII.

Ao mesmo tempo, favoreceu o estabelecimento do secularismo, pois muitos entendiam naquele momento que se a Igreja não era mais capaz de fornecer todas as respostas, era hora de o homem buscar sua independência do sagrado. A sociedade ocidental sentia a necessidade de buscar o conhecimento próprio, sem a mediação da religião.

É neste contexto que surgem e se desenvolvem o contratualismo e as bases do Estado Moderno os quais, entre outras coisas, preveem separação entre Igreja e Estado e

7 De acordo com o site http://mundoeducacao.bol.uol.com.br/historiageral/reforma-protestante.htm. Acesso em 03/04/2017: Cisão na igreja cristã ocidental, ocorrida em 1517 sob a liderança de Martinho Lutero. Os reformadores como o nome sugere, pregavam uma reforma na igreja cristã no sentido de "recuperar a relação com Deus". 
ao mesmo tempo limites ao poder do soberano. Assim, no período contemporâneo, a função jurisdicional ideal funciona sem a influência da Igreja. O Estado só pode punir com base objetiva em ditames legais. Os textos legais seriam, ao menos em tese, aprovados pela população, uma vez que são aprovados pelo parlamento, que o faz em nome do povo na democracia representativa.

Ao se optar, ou direcionar, para um Estado sem orientação religiosa, há uma expectativa de uma racionalização de muitas práticas e métodos do comportamento social, restando isso consignado nos ordenamentos jurídicos do mundo ocidental.

Entretanto, há de se entender que tal processo não ocorreu de forma imediata, constante ou linear ao longo da história da sociedade ocidental. As bases do direito penal laicizado estão na antiguidade clássica (século VIII a.C. - V d.C.), nos direitos grego e romano, conforme exposto no trecho descrito a seguir (PIERANGELI e ZAFFARONI, 2011, p. 168)

\begin{abstract}
Com Grécia e Roma o Direito Penal se laiciza, torna-se marcadamente mundano. Essa não será uma conquista definitiva na história do homem porque, como veremos, há um longo caminho de marchas e contramarchas, mas, de qualquer forma, é o momento em que, na antiguidade, alcança-se o maior grau de laicização.
\end{abstract}

Entre idas e vindas, avanços e retrocesso das formações dos Estados ocidentais e com consequentes influências no mundo jurídico, chega-se ao século XIII, período situado dentro da Idade Moderna (após o medievo) consubstanciado por severas críticas ao domínio da Igreja nos Estados. Tal século foi o escolhido por Anitua (ANITUA, 2008, p. 40) como sendo o grande marco do surgimento de muitos conceitos fundamentais, tais como soberania, Estado, burguesia e capitalismo. 
A esperada separação entre Igreja e Estado não aconteceria em definitivo no século XIII. Ao contrário, o Clero ainda manteria uma grande influência naquele contexto histórico, conforme apontado abaixo (ANITUA, 2008, p.40).

Foi certamente a partir da data escolhida para dar início a este balanço histórico do pensamento sobre o delito e a pena que se verificou uma influência maior dos instruídos sobre a forma de exercício deste novo poder "monárquico" ou de soberania oposto ao poder feudal, no qual a força física era mais valorizada do que a capacidade “administrativa”. Estes instruídos, muitas vezes provinham do interior da igreja.

Talvez esta relação da administração com a Igreja é que leva Anitua a avaliar que no século XIII o direito, justificador e limitador do poder de punição do Estado era totalmente influenciado pelo direito canônico, que previa a inquisição como punição e não dava espaço ao princípio da ampla defesa.

0 tema da judicialização com um viés religioso não admitia uma avaliação objetiva do delito, mas sim uma interpretação subjetiva do caráter do delinquente. A delinquência, por conta disso, seria uma questão de personalidade e não de ação, conforme aponta Carvalho (CARVALHO, 2008, p. 28).

Dessa forma, há uma busca obsessiva pela "verdade" que se permite (ou permitia) alguns excessos por parte da autoridade. 0 réu neste contexto, na avaliação de Anitua (ANITUA, 2008, p. 43) deixa de ser um agente na relação jurídica para ser um objeto do qual seria extraída a confissão, ou seja, a fonte da verdade que embasaria a punição.

Ocorre que ao final da Idade Moderna (século XV a XVIII) surgem pensadores que defendem a maior liberdade econômica e política e o afastamento do Estado do poder da Igreja, ideias configuradas no pensamento iluminista. Trata-se de um período 
propício para os iluministas, pois o mundo ocidental estava em plena transição entre a Idade Média (séculos V e XV), também conhecida como Idade das Trevas - marcada pela forte influência religiosa e restrição de liberdades, e a Idade Contemporânea (a partir do ano 1789 - Revolução Francesa), tempo das liberdades individuais, os franceses as chamavam de liberdades públicas.

Tais ideias influenciariam sobremaneira a Europa Ocidental naquela época, com reflexos no mundo jurídico. Desenvolve-se a ideia de Contrato Social, primeiramente nos moldes hobbesianos (CARVALHO, 2008, pp. 40-41), sendo que na busca de paz e de segurança, o indivíduo entrega parte de sua liberdade para o poder estatal. Este Estado, porém, tem um poder limitado para investigar, para julgar e para punir. Torturas como havia no período anterior não seriam mais aceitas. Assim como o indivíduo tem de respeitar as normas, o Estado passaria a obedecer a regras também. É o que se compreende como a passagem da sociedade do privilégio para a sociedade do contrato, ou seja, passou a evidenciar uma relação entre Estado e súditos, e não mais entre Estado e servos.

Ao contrário do que havia na época medieval, espera-se, aqui, que o réu seja uma parte na relação processual e que possa se defender adequadamente. Será julgado por sua ação e não por sua personalidade, como ocorria no modelo inquisitorial.

Assim analisa Carvalho, fazendo uma comparação entre o modelo inquisitivo e o garantismo como modelo:

Logo, se a sanção no modelo garantista é uma resposta jurídica à violação da norma (quia prohibitum), no modelo inquisitivo traveste-se em resposta quia peccatum, punindo-se o infrator não pelo resultado danoso produzido, mas por quão perigoso ou perverso é.

A partir das ideias difundidas no iluminismo, deixaria de se haver o julgamento baseado na moral, nos ensinamentos religiosos, 
para haver uma avaliação objetiva de cada caso baseado no direito, propiciando assim ao acusado uma possibilidade de defesa.

\section{INFLUÊNCIA DO ILUMINISMO NO DIREITO}

Se o postulado da liberdade é um dos pilares do iluminismo, também é fato de que o limite aos poderes do Estado é fundamental para a realização do ideal iluminista. Por conta disso, o poder de punição tem de sofrer severas limitações, de modo que o acusado tenha plenas condições de se defender da intervenção estatal, no sentido de não sofrer com penas injustas e cruéis.

Tal limitação é dada pela lei que elenca (ou deve elencar) objetivamente o que é delito, para que o julgador não venha a impor uma sanção baseada em um desejo pessoal; e define, em abstrato, as regras do processo. Também é fundamental a separação do papel do acusador em relação ao juiz do processo, evitando suspeição ou parcialidade. 0 juiz do processo, sinale-se deve ter um papel de isenção e apenas julgar com base no que for trazido aos autos pela acusação e pela defesa.

Dentro dessa lógica, é fundamental definir o delito em abstrato com base não na moral, mas na agressão à sociedade que o ato provoca. A importância disso está no fato de que na visão iluminista do direito penal, este deve ser objetivo, na medida em que deve ser garantido a plena defesa ao acusado que tem o direito de saber previamente do que está sendo acusado e como deve ser processado, mediante um julgamento hígido com base em normas legais e não em valores morais.

Carvalho (CARVALHO, 2008, p. 41) avalia que uma vez estabelecidas as regras de convivência entre as pessoas, outrossim definidos os direitos e deveres do Estado e dos cidadãos, não cabe à Administração Pública fazer julgamento com base na moral, pois seria um juízo meramente subjetivo. As normas devem ser prévias e positivadas: 
A intervenção é legítima somente quando a conduta (ativa ou omissiva) causar perceptível dano externo. Com a laicização do Estado e do direito, o crime não corresponde mais à violação do divino, mas à livre e consciente transgressão da norma jurídica promulgada pelo Estado, submetendo o infrator à penalidade retributiva decorrente do inadimplemento: para os clássicos o crime é um fato do homem, não no seu pensamento (de internis non curat praetor) ou no seu modo de ser (periculosidade do indivíduo que comete um crime).

Nesse diapasão, convém trazer à discussão as ideias de importantes pensadores do iluminismo tais como Hobbes e Locke em análise feita por Carvalho (CARVALHO, 2008, pp.28-31). Com o fim do jugo da Igreja e dos senhores feudais, a sociedade passaria a experimentar uma liberdade inexistente no período do medievo.

Nas visões de Hobbes e Locke, sem nenhum limite, tal liberdade poderia descambar para o estado de guerra onde alguns homens poderiam ameaçar a liberdade por meio da violência. Nesse contexto, surge a ideia do Estado Civil, ensejando divergência entre os pensadores, de modo que Hobbes defendia um Estado autoritário bastante limitador das liberdades para evitar o que chamava de barbárie. Por outro lado, Locke, em sua visão de Estado Civil, aceitava o limite à liberdade do cidadão, entretanto, considerava necessária uma limitação na atuação do Estado. Para ele, o Estado Civil é um pacto de deveres e direitos recíprocos, portanto impõe limites ao cidadão e ao Estado. Daí o limite às punições defendido pelos garantistas (CARVALHO, 2008, p. 32).

A perspectiva contratualista, portanto, fornece 0 solo fértil ao pensamento garantista, visto que assentada na limitação dos poderes pela legalidade: a tutela dos direitos do homem contra os poderes privados com a negação do estado de natureza e 
a opção pelo estado civil; a proteção dos direitos do cidadão contra o abuso dos poderes públicos, desde uma perspectiva limitadora do exercício da violência estatal.

Na avaliação de Salo de Carvalho, desenvolve-se a ideia da tolerância, onde um Estado altamente limitado atua na vida e gerencia os conflitos entre os cidadãos, lidando de forma pública com aquilo que é público, deixando-se as questões privadas para o foro íntimo. Proposta identificada com a secularização. A rigor, trata-se da ruptura entre os juízos individuais internos (morais) e externos (direito).

Luigi Ferrajoli, jurista italiano, desenvolve sua teoria no mesmo sentido no livro Direito e Razão - Teoria do Garantismo Penal, no qual ele aborda o tema fazendo uma análise crítica da influência da moral no direito e vice-versa. Ele avalia que o mérito do pensamento penal iluminista foi reconhecer os nexos entre garantismo, convencionalismo legal e cognitivismo jurisdicional de um lado, contra despotismo, substancialismo extralegal e decisionismo valorativo.

Para Ferrajoli (FERRAJOLI, 2002, p. 39), "o modelo iluminista da perfeita 'correspondência' entre previsões legais e fatos concretos e do juízo como aplicação mecânica da lei é uma ingenuidade filosófica viciada pelo realismo metafísico". Ou seja, ainda que ideal, o modelo iluminista tinha limitações práticas.

Referido jurista italiano em muitas passagens faz um contraponto entre o formalismo e o substancialismo realçando a importância, na ótica garantista, de a decisão ser a mais resguardada possível nos ditames legais. Ao mesmo tempo em que defende esta tese, reconhece que há um grande contingente de elementos externos ao processo que acabam por "contaminar" as decisões. Evitar tal "contágio" seria o grande desafio dos julgadores.

A defesa do convencionalismo legal, ou seja, de uma prática penal que inclua uma definição legal e objetiva dos delitos, prefe- 
rencialmente sem margem subjetiva de análise, faz todo sentido na lógica iluminista. Nessa senda, também corrobora os preceitos da Constituição Brasileira que no seu artigo 5o prevê os princípios fundamentais da Legalidade, da Ampla defesa e o do Devido Processo legal, entre outros. Ora, se a sociedade está convivendo em um contrato tácito, as regras devem ser bem definidas, aceitas e formuladas por todos - este é o papel do Poder Legislativo -. Dentro da lógica garantista e liberal, o acusado tem que estar ciente do teor da acusação e como o processo irá se desenvolver.

Não é possível, na ideia do contrato social, que um dos integrantes do pacto, ainda que o tenha transgredido, dependa única e exclusivamente da boa vontade do Estado ou de um juiz em seu julgamento. Assim, o princípio da ampla defesa deve prevalecer e ao Estado é proibido alterar as regras do jogo. Há de se compreender que embora o contrato disponha sobre a entrega de parcela da liberdade do cidadão ao Estado, por outro lado, o mesmo contrato limita o poder do Estado.

E tal limite é conferido pela lei. A mesma lei que limita o Estado também serve para igualar os cidadãos que têm suas liberdades limitadas. A possibilidade de fazer as leis encontra sua legitimação no princípio da soberania do povo (HABERNAS, 2012, pp. 114-115).

O direito moderno tira dos indivíduos o fardo das normas morais e as transfere para as leis que garante a compatibilidade das liberdades de ação. Estas obtêm sua legitimidade no processo legislativo que, por sua vez, se apoia no princípio da soberania do povo.

Outros autores entendem da mesma forma e visualizam a influência iluminista muito forte no garantismo. Carvalho, por exemplo, deixa isto bem explícito ao analisar que as bases do Direito Penal são oriundas do contrato social. Este seria um pacto 
o qual teria tido adesão de pessoas capazes que se submetem a uma pena em decorrência da violação do acordo.

A apuração da violação se daria em um procedimento totalmente previsto em lei (CARVALHO, 2008, p. 41):

(...) comprovada [a violação do contrato] em processo contraditório e público, orientado pela presunção de inocência, com atividade imparcial de magistrado que valora livremente a prova (sistema processual acusatório). Assim, percebe-se claramente um programa de intervenção penal limitada cuja centralidade é a tutela dos direitos individuais contra os poderes irracionais, públicos (Estado) e/ou privados. Sem embargo, tal concepção possibilita um entendimento, ainda que não explícito, pessimista do poder estatal, pois geneticamente propenso à violação dos direitos fundamentais da pessoa humana.

Nessa ótica, ao mesmo tempo em que a sociedade entrega o monopólio da violência ao Estado, limita este poder por meio das leis. De toda sorte, o mesmo autor prevê como permitida a violência privada somente em caso de legítima defesa, ou seja, a resposta proporcional a uma violência injusta por parte de outro cidadão.

Depreende-se que pelo modelo garantista desenvolvido a partir do iluminismo, há de se primar pela separação/diferenciação entre direito e moral, bem como, pela busca de um processo e posterior aplicação de pena justa, em consonância com o devido processo legal e da ampla defesa, princípios fundamentais na constituição brasileira.

Pois bem, na lógica do pensamento iluminista, nada pode ser imputado ao cidadão sem que haja previsão legal. Ao mesmo tempo, as normas devem ser elaboradas levando-se em conta bens que devam ser tutelados pelo Estado por sua relevância para a sociedade tais como a vida, a propriedade, ou a liberdade. 
Nesse sentido, não há de se falar em delitos baseados em valores morais, ou mesmo definidos por crenças religiosas, pois estas, fazem parte da seara particular e devem ser assim resolvidos.

\section{A MORAL E O DIREITO NO COTIDIANO DO JULGADOR CONTEMPORÂNEO}

Para ilustrar o que foi até aqui exposto neste artigo, utilizou-se a título de subsídio um apanhado de sentenças com trânsito em julgado afetas a crimes de roubo seguido de morte (artigo 157, § 3ㅜㅡ "in fine") na comarca de Gravataí-RS. 0 delito escolhido foi o latrocínio pelo fato de haver uma grande reprovação social e também pelo fato de ter a expectativa de se analisar todos os fatos com trânsito em julgado.

A ideia é verificar se há uma manifestação absolutamente objetiva, baseada na lei, ou se há algo de subjetivo que leva em conta o caráter do réu ou mesmo a reprovação ao delito. Dessa maneira, é possível perquirir se a secularização é incidente nos casos em comento, ou seja, se temos mesmo um Estado laico na prática jurisdicional ou se a moral e a religião ainda influenciam os magistrados atualmente.

Há de se observar, como afirma Ferrajoli, que o juiz não é uma máquina, logo está sujeito a certo grau de influência externa. 0 que se tem de analisar é o quanto o julgador está sendo influenciado.

Nesse contexto, é mister se levar em consideração a lição de Ferrajoli (FERRAJOLI, 2008, p. 33) sobre a separação entre direito e moral:

(..). Somente por convenção jurídica, e não por imoralidade intrínseca ou por anormalidade, é que um determinado comportamento constitui delito; e a condenação de quem se tenha comprovado ser responsável não é um juízo moral nem um diagnóstico sobre a natureza anormal ou patológica do réu. Disso resulta excluída, ademais, toda função 
ética ou pedagógica da pena, concebida como aflição taxativa e abstratamente preestabelecida pela lei, que não pode ser alterada com tratamentos diferenciados do tipo terapêutico ou correcional.

Foram feitas análises em alguns dos processos com condenação pelo delito de latrocínio dos 1095 investigados no gênero Roubo e Extorsão. Por uma questão de preservação às identidades das pessoas envolvidas nas ações, o número foi substituído pelo nome "Sentença", seguido de um numeral.

No processo denominado "Sentença I", o réu foi condenado por ter matado (junto com um adolescente) a vítima com a intenção de subtrair dinheiro desta para a compra de drogas. A seguir serão colocados alguns trechos do julgado:

Os agentes atuaram de forma desumana e com frieza no evento. Além de matarem um ser humano, o crime ficou ainda mais repugnante se considerada a quantia que motivou o ilícito - $\mathrm{R} \$ 15,00$ (quinze reais) - incentivando a simples banalização da vida alheia para o réu.

Pode se verificar que na análise feita pelo julgador, precisamente na descrição da conduta do agente ao matar a vítima, há uma valoração que vai além daquela referente aos elementos do tipo penal ou da dosimetria da pena. Há uma avaliação da pessoa do réu em trechos como aqueles sublinhados (sinalização adicionada pelos autores deste ensaio, não consta da sentença original). Em outro trecho, na descrição da conduta social, afirma que o réu "Não possui senso de humanidade e respeito para com o próximo, agindo com descaso face aos membros da sociedade". Uma avaliação bastante dissociada do jurídico e com cunho moral ou mesmo religioso.

Note-se que o elemento conduta social, conforme entendimento doutrinário, serve para analisar "o comportamento de- 
senvolvido pelo agente na comunidade em que vive, abrangendo as suas relações familiares e de vizinhança..." (FRANCO e STOCO, 2007, p. 345). Ou seja, uma análise da vida social do agente de modo a verificar como vive em sua comunidade. Mas no julgado em questão, há uma valoração da relação com a sociedade com base no delito cometido, o que não é, de forma alguma a ideia do artigo 59. A conduta em si no delito, já é analisada quando da verificação do crime propriamente dito.

Na verdade, o termo "conduta social", por si só, é bastante questionável. Conforme pontuam Carvalho e Carvalho tal elemento confunde-se muitas vezes com os antecedentes, uma vez que se originou deste. Além disto, serviria para reforçar a culpa do agente, o que violaria o princípio da secularidade (CARVALHO e CARVALHO, 2002, p. 53):

Estabelecido critério temporal de limitação dos efeitos dos antecedentes, necessário ainda afirmar que o instituto afronta, em absoluto, o princípio da secularização, pois entendemos que o dispositivo legal agregado à circunstância conduta social, reforça ainda mais a culpabilidade de autor em detrimento da culpabilidade de fato (...)

No processo "Sentença II", os réus foram condenados por terem assaltado um mercado culminando na morte de um policial militar e no roubo da arma deste. 0 julgador, talvez pelas circunstâncias do fato, faz uma avaliação dotada de subjetividade com expressões que denotam uma análise que vai além dos elementos jurídicos.

Como pode ser visto no item a seguir:

(...) a expressiva violência empregada no evento igualmente impressiona. Como perceberam a presença da vítima em frente ao mercado, sabendo que este era policial militar, passaram a desferir 
diversos disparos de arma de fogo contra ele, que somente esboçou reação após ter sido alvejado e já de joelhos no chão, ferido. Não satisfeitos, após vítima já estar rendido e inconsciente, um dele aproximou-se e, friamente procurou regiões letais de seu corpo, desferindo novos disparos, acertando o policial na nuca, pelas costas, além de mirar a arma em seu pescoço e peito, desferindo os disparos letais, fazendo com que a vítima caísse ao solo, ocasião em que levantou seu corpo e subtraiu a arma de fogo do policial, que estava caída debaixo do corpo da vítima, já desfalecido, saindo calmamente do local, caminhando, já que certo da impunidade garantida pelo réu Carlos, o que configurou circunstância ainda mais repulsiva.

Note-se nas expressões sublinhadas (sinalização gráfica que não consta na sentença original) que o julgador se valeu de uma série de adjetivos e palavras que excedem à avaliação meramente judicial. São elementos que não constam da descrição do delito no Código Penal, tampouco no artigo 59 do referido diploma legal, logo são do uso pessoal do magistrado, evidenciando-se subjetividade no julgamento.

Em razão do secularismo vigente no país, refutam-se sentenças que incriminam meros estados pessoais do agente, que é o caso em análise. Ora, se circunstâncias como "friamente" ou ainda "mais repulsiva" constam já na análise do delito, e não fazem parte de sua descrição no Código Penal, é mera valoração do julgador de aspectos pessoais do réu, conforme (CARVALHO e CARVALHO, 2002, p. 30)

O princípio da secularização, instrumentalizado por toda cadeia constitucional, é plenamente aceito pela dogmática tradicional como limitador da atividade legislativa em sua corporificação no princípio da taxatividade. Assim, é fácil encontrar nos autores ampla refutação de normas que incri- 
minam meros estados pessoais e convicções, isto é, normas penais constitutivas.

Tal situação também pode ser observada no processo "Sentença III", no qual o réu é condenado por ter subtraído bens de uma das vítimas, além de feri-la gravemente, e ter matado outra a golpes de martelo. Se na avaliação dos elementos do tipo penal o julgador conserva certa objetividade, na análise de itens da dosimetria tais como conduta social "não possuindo senso de humanidade e de respeito para com o próximo" a sentença é carregada de avaliação moral. Como também pode ser notado no item as seguintes circunstâncias:

Após subtrair o dinheiro e desferir vários golpes de martelo contra a cabeça das vítimas, o réu as abandonou ainda lúcidas, enquanto agonizavam em sofrimento. Igualmente, o réu conhecia I, que já havia lhe ajudado financeiramente com empréstimo de dinheiro, além de ser seu antigo colega de trabalho.

Denota-se uma descrição detalhada do item utilizando-se de elementos que tendem a trazer alguma valoração moral à análise, visto que apela à empatia, à fidelidade, ao companheirismo, etc., elementos que não fazem parte do tipo penal, nem do artigo 59 do Código Penal.

0 réu foi condenado por subtrair uma arma da vítima e matá-la, mediante disparo de arma de fogo, no processo "Sentença III". No julgado, os elementos componentes do delito são apresentados de forma objetiva, no entanto há bastante subjetividade no que tange à dosimetria da pena.

Chama atenção, em especial, o item "Conduta social" :

Não possui senso de humanidade e respeito para com o próximo, agindo com descaso face aos mem- 


\begin{abstract}
bros da sociedade. A confirmar tamanho descaso para com a coletividade está o fato de a vítima ter sido morto por disparo de arma de fogo neste evento a que deu causa o réu, e ter sido abandonado no local, somente tendo sido localizado o corpo por um vizinho, no dia seguinte.
\end{abstract}

Anote-se no conteúdo acima exposto, que o julgador faz uma avaliação com conteúdo que extrapola o jurídico e tem conotação de moralidade ao exigir, ou esperar, senso de humanidade ou respeito ao próximo. Contudo, conduta social "É o papel do réu na comunidade, inserido no contexto da família, do trabalho, da escola, da vizinhança etc." (NUCCI, 2011, p. 469), logo é a forma como o sujeito insere-se em seu meio e não uma relação dele com a sociedade em geral, portanto, no julgamento não caberia ser trazidos à baila elementos da personalidade do réu.

\title{
CONSIDERAÇÕES FINAIS
}

0 presente artigo visa à verificação da vigência da laicidade e do secularismo na atuação jurisdicional na atualidade. Para isso, foi analisado um tipo penal específico concernente ao roubo seguido de morte (latrocínio) previsto no artigo $157, \S 3^{\circ}$, in fine, do Código Penal. A razão pelo qual foi escolhido o referido tipo penal foi a repulsividade social, bem como a possibilidade de se analisar um grande percentual dos processos com trânsito em julgado.

Releva considerar que, na análise dos julgados sob testilha, vislumbrasse subjetividade com opiniões do julgador eivadas de avaliação moral ou religiosa, cujos fundamentos influenciaram na dosimetria da pena. Nesse contexto, os julgadores fazem avaliações do acusado e não do delito, uma vez que há o uso de expressões tais como "senso de humanidade" ou "tendo liberdade de escolha no seu proceder, optando pela execução dos crimes", que corroboram essa noção de critérios eminentementes subjetivos. 
Por fim, em face do exposto neste breve ensaio, é possível concluir que há avaliação moral nas sentenças em comento. Evidencia-se um excessivo uso de expressões altamente valorativas, de cunho moral e religioso em muitos dos julgados analisados, revelando que os critérios de cunho axiológico se sobrepõem aos critérios objetivos da norma. Ou seja, a laicidade e o secularismo nos julgados observados não são aplicados em sua plenitude, ponderando-se, no entanto, que a adoção de critérios morais/ axiológicos/ religiosos permeiam o ordenamento jurídico, mormente, no contexto deste ensaio, na exegese do artigo 59 do Código Penal.

\section{REFERÊNCIAS}

Dicionário Eletrônico Aurélio. 4aㅗ Ed. Positivo Informática Ltda. 2009.

ANITUA, Gabriel Ignacio. História dos Pensamentos Criminológicos. 1ạ.ed. Rio de Janeiro: Editora Revan, 2008. Tradução: Sérgio Lamarão.

BAUMER, Franklin L. O Pensamento Europeu Moderno Volume I Séculos XVII e XVIII. Edição portuguesa, Lisboa/Portugal: Edições 70,1977. Tradução: Maria Manuela Alberty.

CARVAlHO, Salo de; CARVAlHO. Amilton Bueno de. Aplicação da Pena e Garantismo. 2 ${ }^{a}$ Ed., ampliada. Rio de Janeiro: Lumen Juris, 2002

CARVALHO, Salo de. Penas e Garantias. $3^{\text {a }}$. ed. Rio de Janeiro: Lumen Juris, 2008.

Revisita à Desconstrução do Modelo Jurídico Inquisitorial. Revista da Faculdade de Direito UFPR. Disponível em http://revistas.ufpr.br/direito/article/viewFile/5183/3898. Acesso em 10/10/2016.

FERRAJOLI, Luigi. Direito e Razão - Teoria do Garantismo Penal. 3ä.ed., São Paulo: Editora Revista dos Tribunais, 2002. Tradução: Ana Paula Zomer Sica, Fauzi Hassan Choukr, Juarez Tavares e Luiz Flávio Gomes.

FRANCO, Alberto Silva; STOCO, Rui (org.). Código Penal e Sua Interpretação: Doutrina e Jurisprudência. $8^{\mathrm{a}}$.ed. revista, atualizada e ampliada. São Paulo: Editora Revista dos Tribunais, 2007. 
GAUER, Ruth M. Chittó. A Fundação da Norma - Para Além da Racionalidade Histórica. 1a. ed., Porto Alegre: EDIPUCRS, 2009.

NUCCI, Gilberto de Souza. Manual de Direito Penal: Parte Geral/ Parte Especial. 7ạ.ed. revista, atualizada e ampliada. São Paulo: Editora Revista dos Tribunais, 2011.

PIRATELI, Marcos Roberto; PEREIRA MELO, José Joaquim. Agostinho e a Igreja Como Espaço de Formação no Fim da Antiguidade. Revista Jornada de Estudos Antigos e Medievais (http://www.ppe.uem.br/jeam/ anais/2013/pdf/42.pdf acessado em 10/10/2016).

WEBER. Max. A Ética Protestante e o Espírito do Capitalismo. $2^{\text {a }}$ Ed. São Paulo: Editora Pioneira Thomson Learning, 1981.

ZAFFARONI, Eugênio Raul. 0 Inimigo no Direito Penal. 3ạ. ed., Rio de Janeiro: Editora Revan, 2011.

; PIERANGELI, José Henrique. Direito Penal Brasi-

leiro Volume 1. 9ạ. ed., São Paulo: Editora Revista dos Tribunais, 2011. 